\title{
TOPOMORPHOLOGICAL COMPARTMENTS AND MORPHODYNAMICS OF AN URBAN STREAM WATERSHED, UBERABA, BRAZIL
}

Francisco Ferreira Martins Neto

Universidade Federal do Triângulo Mineiro

Programa de Pós-graduação em Ciência e Tecnologia Ambiental, Uberaba, MG, Brasil neto.fm@hotmail.com

Felipe Ivonez Borges Alexandre Universidade Federal do Triângulo Mineiro Programa de Pós-graduação em Ciência e Tecnologia Ambiental, Uberaba, MG, Brasil engeofelipe@gmail.com

Fabricio Anibal Corradini Universidade Federal do Triângulo Mineiro Programa de Pós-graduação em Ciência e Tecnologia Ambiental, Uberaba, MG, Brasil fabricio.corradini@uftm.edu.br

\begin{abstract}
The urban expansion experienced by Uberaba County (MG) from the 1970s on has changed not only the life of the local population, but also the physiography of the urban area due to channeling of major streams. Changes in surface runoff have been causing several inconveniences to the population due to flooding events resulting from heavy rainfall periods. Recent studies have reported association between the increased frequency and intensity of such events after waterproofing key areas to avoid surface water infiltration. Lages stream is located downtown Uberaba, which is a place of economic and social interest that is highly vulnerable to floods. Thus, it is necessary investigating its watershed to help better understanding its topomorphological compartments and morphodynamics, as well as to analyze the influence occupation and anthropization processes on its natural dynamics. Maps depicting waterproofed areas, watershed boundaries, digital elevation model and transects were generated in QGIS 2.18, whereas physiographic features were calculated based on the main methods available in the literature. The aforementioned aspects have indicated that the watershed has natural susceptibility to flooding events. Three topomorphological compartments were identified, namely: valley bottom, mid-slopes and smoothly waved tops. The large number of waterproofed regions within the watershed, mainly in low-slope sections of it, intensifies the surface runoff in the area and increases the incidence of flooding events in the urban section of it.
\end{abstract}

Keywords: Urban geomorphology. Urban basin. Flooding events.

\section{COMPARTIMENTOS TOPOMORFOLÓGICOS E MORFODINÂMICAS DE UMA BACIA HIDROGRÁFICA URBANA, UBERABA, BRASIL}

\section{RESUMO}

A expansão urbana ocorrida no município de Uberaba (MG) a partir da década de 1970 mudou não apenas a vida da população local, mas também a fisiografia da área urbana devido à canalização dos principais rios urbanos. Alterações no escoamento superficial têm causado vários inconvenientes à população devido a eventos de inundação resultantes de períodos de fortes chuvas. Estudos recentes relataram associação entre o aumento da frequência e intensidade de tais eventos após a impermeabilização de áreas-chave reduzindo a infiltração de águas superficiais. O córrego das Lages é um deles. Está localizado no centro da cidade, constituindo um local de importância econômica e fluxos sociais altamente vulneráveis a inundações. Assim, é necessário investigar sua bacia hidrográfica para ajudar a entender melhor seus compartimentos topomorfológicos e morfodinâmicos, bem como analisar a influência dos processos de ocupação e antropização em sua dinâmica natural. Mapas representando áreas impermeabilizadas, limites de bacias hidrográficas, modelo de elevação digital e transectos foram gerados no QGIS 2.18, enquanto as características fisiográficas foram calculadas com base nos principais métodos disponíveis na literatura. Os aspectos acima mencionados indicaram que a bacia hidrográfica tem suscetibilidade natural a eventos de inundação. Foram
\end{abstract}


identificados três compartimentos topomorfológicos, a saber: fundo do vale, encostas médias e topos ondulados. O grande número de regiões impermeabilizadas dentro da bacia hidrográfica, principalmente em seções de baixa inclinação, intensifica o escoamento superficial nas áreas adjacentes e aumenta a incidência de eventos de inundação na área central da cidade.

Palavras-chave: Geomorfologia urbana. Bacia hidrográfica urbanizada. Eventos de inundação.

\section{INTRODUCTION}

Cities are complex systems that can affect natural landscapes and increase the vulnerability of certain places, mainly due to the construction of homes and other urban infrastructures (ANCHUELA et al., 2015). Changes in environmental systems are inevitable during anthropic occupation processes, since such systems start incorporating other structures such as buildings, channeling and rectification of drainage networks, soil sealing, green area limitation, among others, which transform their natural dynamics.

Thus, it is necessary analyzing urban expansion based on geomorphological sciences perspective to help better understanding landscape structuring processes, since studies are essential to gather valuable information about environmental processes and dynamics, which are not often approached from the engineering perspective.

Overall, only economic and social parameters are taken into consideration during the planning, development and management of urban environments. Consequently, it results in the occupation of vulnerable places, which can bring harm to society and to the economy due to potential tragedies (BATHRELLOS et al., 2012). According to Berhane and Walraevens (2012), it is necessary investigating the geomorphology and geology of places to be occupied, or places whose infrastructure was already installed, to enable coherent urban planning processes. With respect to the last case, geomorphological and tectonic analyses can be important tools used to identify terrain shapes and environmental conflicts, as well as to help mitigating them.

Uberaba (MG), which is located in Triângulo Mineiro region - Brazil, has a steeply sloped area in its urban perimeter. This aspect, in association with geomorphological features and inadequate human occupation processes that mainly happen in places near tributaries that present natural tendency to be flooded, leads to several issues, such as river water overflow and floods, and brings harm to society.

This scenario can be seen in Lajes Stream watershed, which covers virtually the entire urban perimeter of Uberaba, whose main avenues and trading center are located over valley bottoms and their tributaries. Its surrounding area holds the largest waterproofed sites, which result from a long real estate speculation and urban densification process. Urban infrastructures, in association with lack of riparian vegetation and with the channeling of almost all streams, have transformed the morphology of the site and significantly worsened the weaknesses of the environmental system. Thus, the aim of the current study is to analyze morphological elements and processes seen in the environmental system of Lajes Stream watershed, Uberaba, to help better understanding its topomorphological compartments based on the influence human occupation and anthropization processes have on the natural dynamics of the aforementioned environmental system.

\section{STUDY SITE}

Lajes Stream watershed is located mainly in the urban area of Uberaba, between the following geographical coordinates: latitude $19^{\circ} 05^{\prime} 03^{\prime \prime} \mathrm{S}, 1^{\circ} 37^{\prime} 38^{\prime \prime} \mathrm{S}, 2^{\circ} 07^{\prime} 26^{\prime \prime} \mathrm{S}, 9^{\circ} 24^{\prime} 46^{\prime \prime} \mathrm{S}$ and longitude $47^{\circ} 52^{\prime} 07^{\prime \prime} \mathrm{O}, 47^{\circ} 34^{\prime} 53^{\prime \prime} \mathrm{O}, 47^{\circ} 53^{\prime} 52^{\prime \prime} \mathrm{O}, 48^{\circ} 21^{\prime} 08^{\prime \prime} \mathrm{O}$, as shown in Figure 1 (PMU, 2005a, 2005b).

The geology of the region where the investigated county is located in comprises sedimentary rocks belonging to the geotectonic forms of Paraná Sedimentary Basin; these forms derive from São Bento and Bauru Groups, which, in their turn, date back to the Mesozoic era, more specifically to the Late Cretaceous. São Bento Group is represented by Botucatu and Serra Geral Formations, whereas Bauru Group is represented by Araçatuba, Marília, Presidente Prudente, São José do Rio Preto, Rio do Peixe Valley and Uberaba Formations (CODEMIG, 2017). 
With respect to Domains, Uberaba county is inserted in the region of Phanerozoic Sedimentary Basins and Covers. According to IBGE (2009), the geomorphological units place the region at high altitudes in the Northern Plateau of Paraná Basin, in areas where erosion processes are more severe than sedimentation processes.

Figure 1 - Map showing the location of the study site in Lajes Stream watershed, Uberaba, 2018.

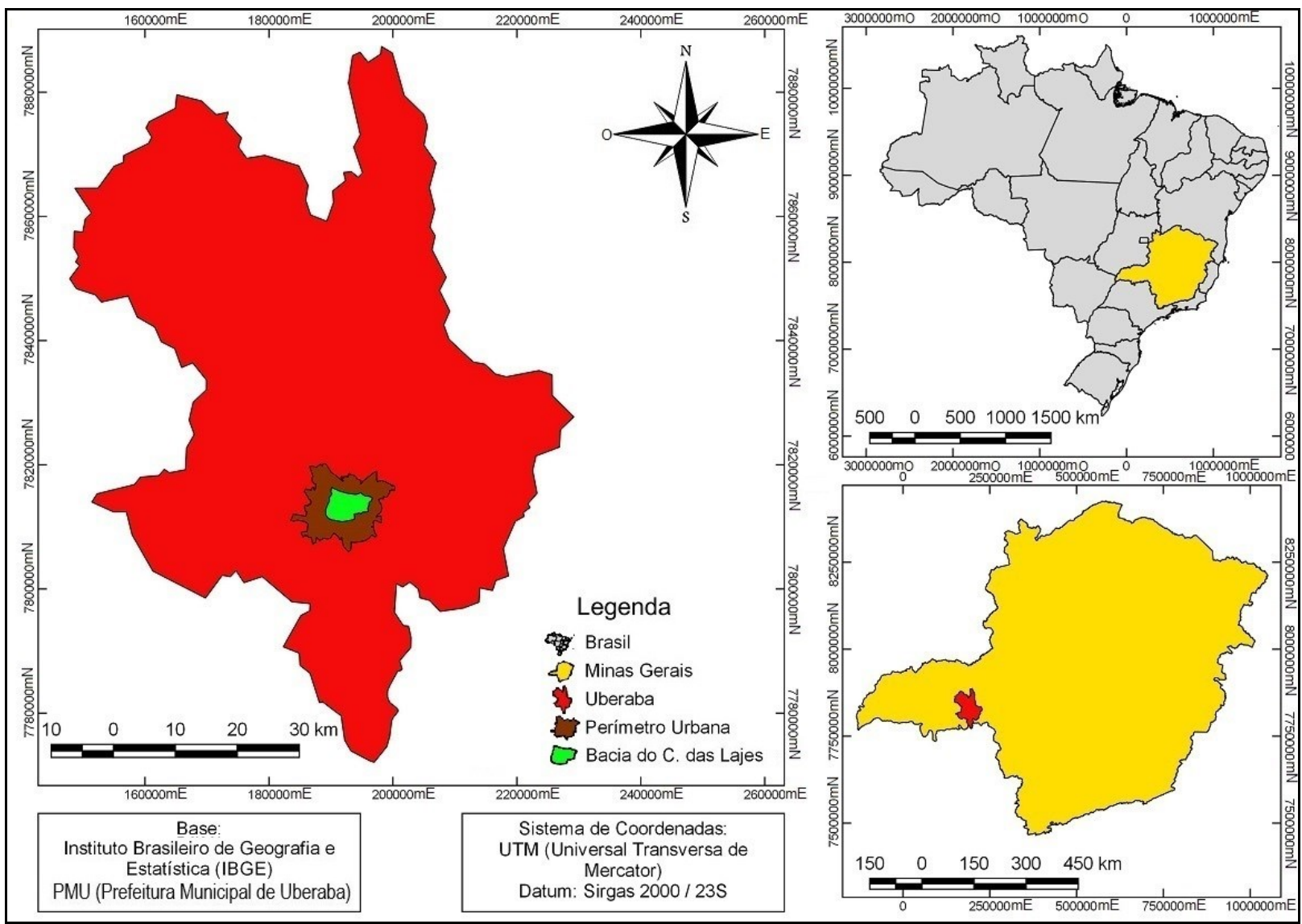

Org. - by the Authors, 2018.

The county is located in a geomorphological unit known as slightly dissected plateau, whose terrain has convex tops leveled between 750 and 900 meters, as well as slopes ranging from $3^{\circ}$ and $15^{\circ}$. In addition, its urban perimeter has areas presenting high slope and large unevenness that, in association with recurrent and intense rainfall events, as well as with increasing waterproofing, can favor flood events (BACCARO, 1991; BACCARO et al., 2001; PMU, 2009). According to Rodrigues (2016), these aspects, in association with urban expansion, decrease water infiltration capacity in the soil, increase Hortonian runoff and, consequently, increase the likelihood of river water overflow and flood events.

The watershed houses a tributary drainage network, which is formed by several channeled and rectified canals and covers an area of approximately $26.7 \mathrm{~km}^{2}$; its perimeter has $22.5 \mathrm{~km}$.

According to Morais (2001), Lajes Stream watershed had approximately $61 \%$ of its watercourses channeled (closed), whereas Lajes Stream itself had $43 \%$ of its course channeled. Based on aforementioned study, channeling works carried out in the 1970s were the viable solution for urban mobility and local sanitation issues. According to Sousa, Alamy Filho and Coelho (2016), similar to several Brazilian counties, Uberaba has appropriated its stormwater drainage network, as well as its domestic sewage discharge system, mainly in the downtown area.

Souza (2008) has pointed out that $60 \%$ of the entire urban area in the county is located within Lajes steam watershed, as well as that the aforementioned stream is responsible for draining most of the excess rainfall water. 


\section{METHODOLOGY}

Physical data about the watershed, such as area $\left(\mathrm{km}^{2}\right)$, perimeter $(\mathrm{km})$, length of the main river $(\mathrm{km})$, talweg length $\left(\mathrm{km}^{2}\right)$ and longitudinal sum of the canal $(\mathrm{km})$ were collected to enable calculating the physiographic indices.

Physical indicators of a given watershed enable the morphometric analysis of its natural features based on some geometric parameters; the ones taken into consideration in the current study were compactness coefficient $(\mathrm{Kc})$, shape factor (kf), drainage density (Dd), circularity index (Ic) and sinuosity index (Is).

The arrangement of watercourses followed Strahler's (1952) classification premises, based on Horton (1945). Compactness coefficient (Kc), shape factor (Kf) and drainage density (Dd) were calculated based on Villela and Mattos (1975). Watershed circularity index (Ic) was analyzed based on Cardoso et al. (2006), whereas sinuosity index (Is), which was first introduced by Horton (1945), was calculated based on the adaptation performed by Mansikkaniemi (1970).

Lajes Stream watershed drainage network was generated by Minas Gerais Institute for Water Management (IGAM, 2002) at a scale of 1:50,000. Refinement process was carried out based on images taken in 2018 by the Operational Land Imager (OLI) sensor, which was allocated on Landsat 8 Satellite, at spatial resolution of 30 meters (scene LO82210732018144CUB00; orbit 221, point 074). In addition, data deriving from the Uberaba City Hall project called "Água Viva" were used for the regions presenting channeled watercourses (PMU, 2005a; PMU, 2009a).

Watershed delimitation process was based contour lines provided by Uberaba County Planning Department - isolines were provided at scale of 1:50,000 and 10-meter equidistance; the highest points surrounded the main watercourse and its tributaries. The contour lines were also used to generate the Digital Elevation Model (DEM), based on the Triangulated Irregular Network (TIN) algorithm available in the QGIS 2.18 software. The aforementioned model was used to generate the hypsometric map of the area that, together with the Qgis2threejs plug-in, has generated the threedimensional terrain model. The model was also used to generate the slope map. The soil sealing map was generated based on the supervised classification process of the QGIS 2.18 Software and subjected to Maximum Likelihood classification.

The terrain in the investigated area was analyzed based on topographic profiles, which were prepared by taking into consideration straight line segments in line with the road network. Transects were elaborated in superposition to DEM, starting from the waterbody towards the top of the slope, by taking into consideration perpendicular intersections between the isolines and the transect, in order find the symmetry between both sampled sides. Total length of the transects was 1,000 meters (500 meters to the right and 500 meters to the left, both perpendicular to the waterbody), whenever possible, by taking into consideration the lowest incidence of change of direction. In addition, 2 transects were elaborated based on the same parameters and processes described above; they encompassed the ends of the watershed and covered its whole area.

Finally, Lajes Stream cross-section profile was generated based on the elaboration of a transect along its entire extension - from the source to the mouth - in order to investigate the likelihood of the incidence of steep slopes in the terrain (knickpoints).

\section{WATERSHED PHYSIOGRAPHY}

Stream channeling based on engineering works is intended to control flood events. However, these works do not measure water flow increase, or flow velocity resulting from decrease in the natural meandering of watercourses, which reduces the distance of watercourses by up to 100 times (WESCHE 1985; BROOKES, 1988; PETTS, AMOROS, 1996).

The (re)configuration in the physical environment of Lajes Stream watershed allows seeing places whose slope ranges from undulating to strongly undulating ( $8 \%$ to $28.8 \%$ ) in approximately $21 \%$ of the total watershed area $\left(5.6 \mathrm{~km}^{2}\right)$.

This area comprises terrains characterized by long ramps that, in association with convex tops, naturally contribute to Hortonian (superficial) runoff formation that, in its turn, in association with anthropogenic waterproofing factors, significantly affects rainwater infiltration and introduces a new dynamics in the environmental system. They are transformed into surface-flow generating/producing 
areas, whose energy balance starts in the lower watershed areas. Table 1 shows physiographic indicators of Lajes Stream watershed.

Table 1 - Physiographic indicators of Lajes Stream watershed - Uberaba County - MG.

\begin{tabular}{cc}
\hline Area $\left(\mathrm{Km}^{2}\right)$ & 26.7 \\
Perimeter $(\mathrm{Km})$ & 22.45 \\
Main Watercourse Classification & $3^{\text {rd }}$ order \\
Compactness Coefficient $(\mathrm{Kc})$ & 1.22 \\
Shape Factor $(\mathrm{Kf})$ & 0.43 \\
Circularity Index (Ic) & 0.67 \\
Main River Length (Km) & 7.90 \\
Talweg Length (Km²) & 5.02 \\
Sinuosity $(\%)$ & 36.44 \\
Main Canal Gradient $(\%)$ & 16.15 \\
Sum of Rivers $(\mathrm{Km})$ & 23.56 \\
Drainage Density $\left(\mathrm{km} / \mathrm{km}^{2}\right)$ & 0.88 \\
\hline
\end{tabular}

Org. - by the Authors, 2019.

The compactness coefficient $(\mathrm{Kc})$ of the investigated site was relatively low due to the significant "rounded" shape of the watershed drainage area; compactness coefficient is one of the parameters associated with the likelihood of flood events. Shape factor (Kf) results have shown lower risk of flood events; however, since its value is inversely proportional to $\mathrm{Kc}$, it can be used to compare watersheds presenting similar size.

Drainage density represents the topographic dissection degree resulting from river erosion, in association with other factors such as the number of drainage canals, among others (CHRISTOFOLETTI, 1981). Values ranging from 0.5 and $1.5 \mathrm{~km} / \mathrm{km}^{2}$ correspond to watersheds with regular drainage (VILLELA, MATTOS, 1975; CHRISTOFOLETTI, 1981). Assumingly, this condition applies to the natural dynamics of the site prior to anthropic changes.

This assumption is consistent with Christofoletti (1979), who pointed out that watershed drainage density is influenced by climate, vegetation, lithology, among other features of the drained area. In addition, drainage density changes depending on sediment runoff and transport, besides being sensitive to climate or anthropic changes.

Based on sinuosity classes set by Mansikkaniemi (1970), the main watershed canal was described as "sinuous ( $<30$ and $>39.9 \%)$ ", which increases its susceptibility to flood events. Based on concepts described by Rocha (1997), the herein recorded values have shown that Lajes Stream watershed is susceptible to river water overflow and flood events, since round-shaped watersheds are more likely to experience simultaneous rainfalls throughout their extension. Moreover, the low sinuosity of the main canal leads to higher water flow velocity and, since infiltration processes are compromised by waterproofing (Figure 2), the propensity of the aforementioned weathering conditions increases.

According to Rodrigues (2016), the high index of waterproofed areas in Lajes Stream watershed intensifies surface runoff and influences the incidence of flood events in the urban area of Uberaba.

According to Corrêa (2003), recurrent flood events are consistent with the high waterproofing rate resulting from the suppression of riparian areas to introduce streets and buildings. Based on the anthropic occupation mapping carried out in Lajes Stream watershed, approximately $86 \%$ of its area is waterproofed; this outcome meets data provided to the aforementioned study by Uberaba City Hall. The report indicates that downtown areas show waterproofing rates higher than $80 \%$, whereas some lots present $100 \%$ and residential neighborhoods present $50 \%$ waterproofing, on average. 


\section{LONGITUDINAL AND TRANSVERSAL TRANSECTS}

Geomorphology counts on several tools to study landscapes. Among them one finds the use of transects and topographic profiles that help better understanding the study site, allow observing geomorphological changes and enable decision-making processes.

Transects contribute to the elaboration of topographic profiles that, in association with information about land use and other site features, are essential to help better understanding geomorphological processes taking place in a given area.

Figure 2 - Diagnosis of waterproofed areas (in black) in Lajes Stream watershed. Blank areas indicate non-waterproofed regions in watershed.

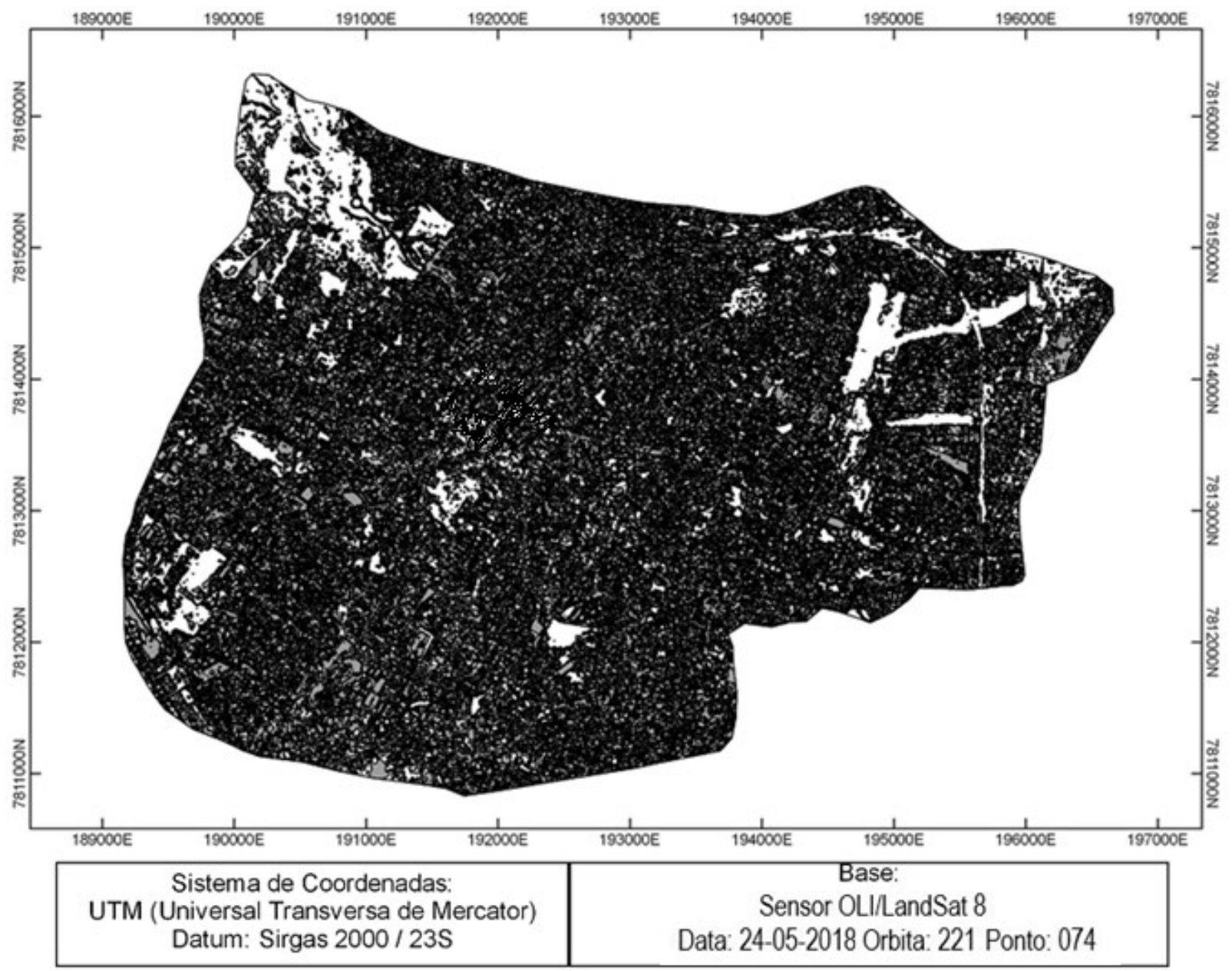

Org. - by the Authors, 2019.

According to Christofoletti (1981), the longitudinal profile of a given watercourse characterizes its slope (gradient), based on the visual representation of the altimetry/length ratio of waterbody regions between the source and the mouth. Low slope regions present decreased surface runoff velocity, a fact that enables areas that can experience flood events in case of inefficient drainage processes, which are typical of waterproofed sites.

Changes in the original features of water canals - such as sinuosity, length, depth, width and slop due to channeling processes lead to Hortonian runoff and to water spatialization in the canal region where its maximum quota and marginal areas once existed.

The longitudinal profile of the main Lajes Stream watershed canal (figure 3), which runs along the main avenue in Uberaba County, presents straight areas in the downtown portion of the county. The 
divergence from the ideal model (concave with larger slopes towards the headwater) is notorious. According to Etchebehere et al (2004), it may indicate recent tectonic activity, as well as hydrological and/or depositional variations, which enable assuming that the canal remains in formation.

Carvalho and Latrubesse (2004) have observed abnormal peaks and protrusions in the profile of Araguaia River canal and concluded that this profile discontinuity, as well as the observed noises, can be associated with the incidence of knickpoints $(\mathrm{Kp})$ produced by rocky outcrops and/or tectonic control.

Channeling-based intervention processes applied to the natural drainage of Lajes Stream watershed may be affecting regions where waterbodies flow without artificial canals, since Kp and rocky outcrops were found in them. This outcome corroborates Oliveira, Reckziegel and Robaina (2006), who concluded that channeling processes based on engineering works increase the erosion of the margins and the width of the canal, as well as that it can also lead to base level changes.

Figure 3 - Longitudinal profile of the main canal under the main avenue in Lajes Stream watershed.
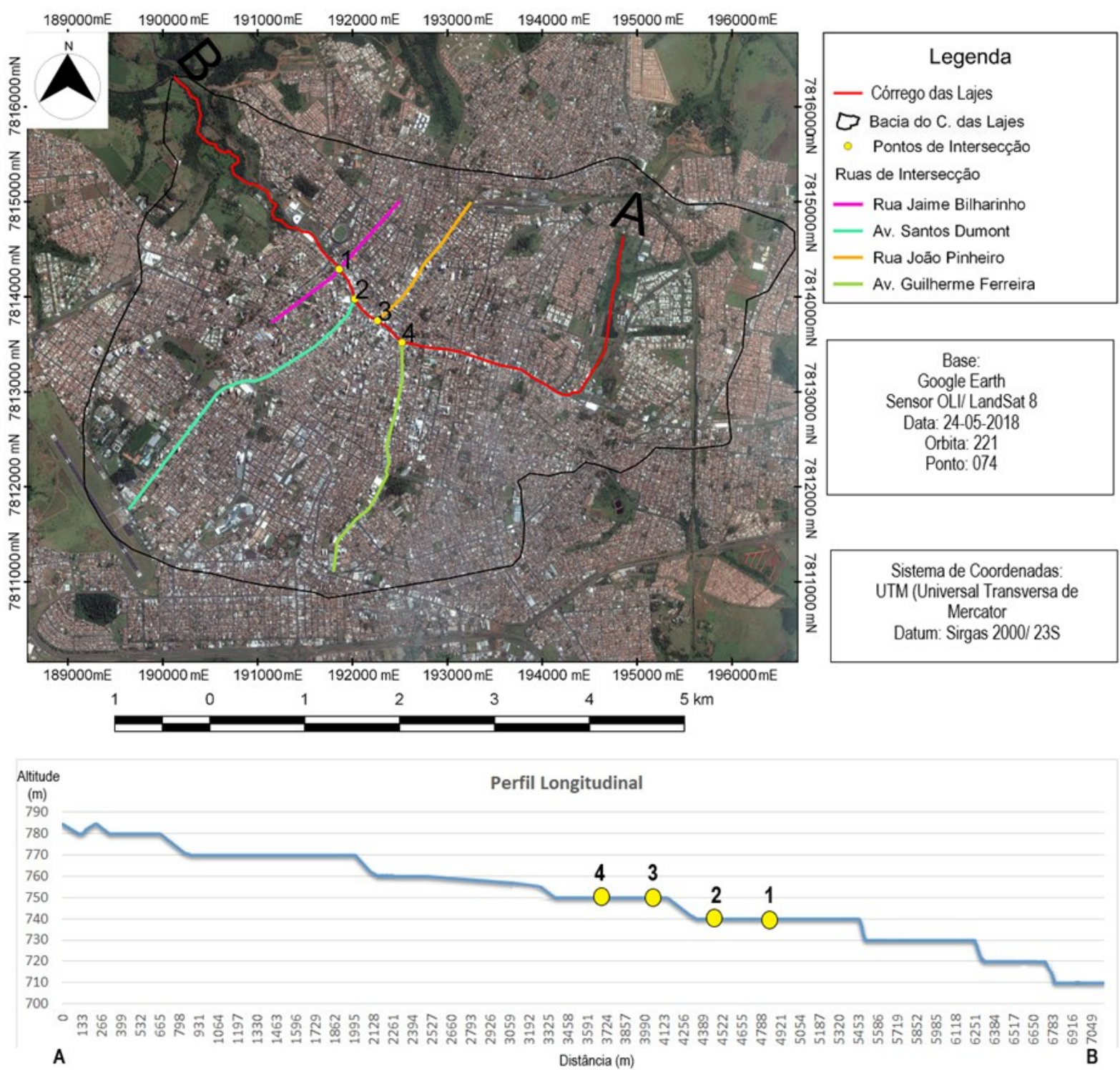

Org. - by the Authors, 2019. 
In order to understand terrain reconfigurations that enable increased surface runoff towards lower altitude areas, transects were elaborated in watershed areas perpendicular to the waterbodies to enable generating 16 topographic profiles distributed along the segment of Lajes Stream and its tributaries, overlapping the road network (Figure 4).

Human activities directly or indirectly displace large amounts of soil, a fact that leads to clear topographic changes in terrain morphology; these changes can affect land surface processes (TAROLLI; SOFIA; CAO, 2018). Based on the topographic profile shown in Figure 5, it is possible observing morphological differences between the right and left sides of Lajes Stream.

The road extension of the profile is perpendicular to the stream, as well as presents straight declivity in the slopes and flat central area. The profile of the region behind the upper margin is asymmetrical to the opposite side of the stream, a fact that may be associated with building foundations, mainly to the presence of laterites, which are characterized by laterization processes taking place in the watershed, which end up changing its the natural morphology. Lajes Stream watershed is within the urban perimeter of Uberaba County; thus, the urban infrastructure (homes, buildings, public facilities, among others) and the road network are distributed around the waterbodies, a fact that turns them into major factors for the new morphometric configuration of the watershed.

Figure 4 - Transects used to prepare topographic profiles in Lajes Stream watershed, Uberaba County - Minas Gerais State.

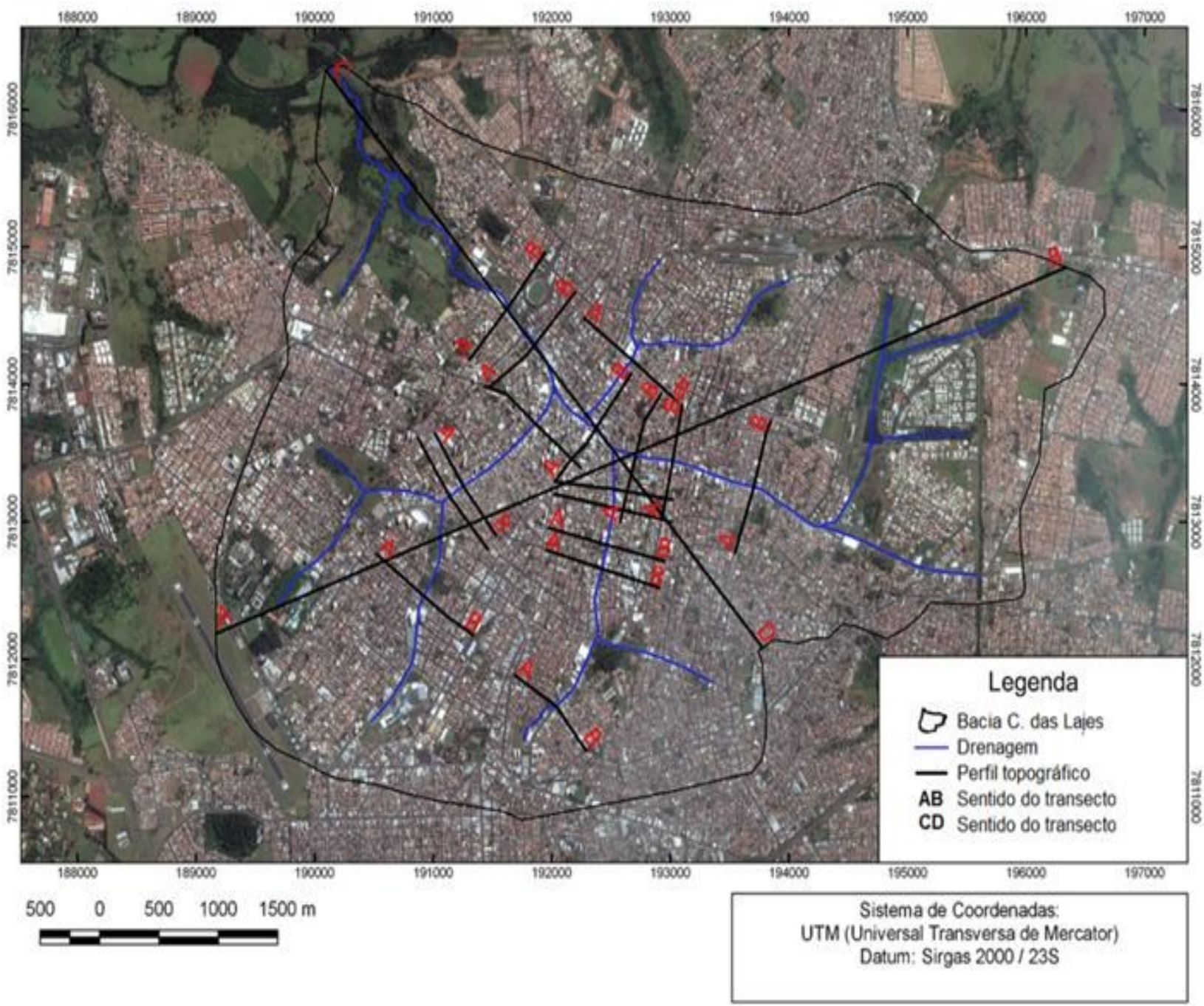

Org. - by the Authors, 2019. 
Asymmetry derives from different intensities in changes taking place in opposite margins; these changes are influenced by the local geological formation, which characterizes the current features arising from the vertical dissection of the terrain that was formed due to extensive pediplanation and laterization (SANTOS; BACCARO, 2004).

Profiles prepared based on transects encompassing watershed extremities (Figures 7 and 8 ) have presented differences in symmetry, as well as variations along the representation.

Figure 5 - Transect (over the road network) used to prepare one of the topographic profiles in Lajes Stream watershed.
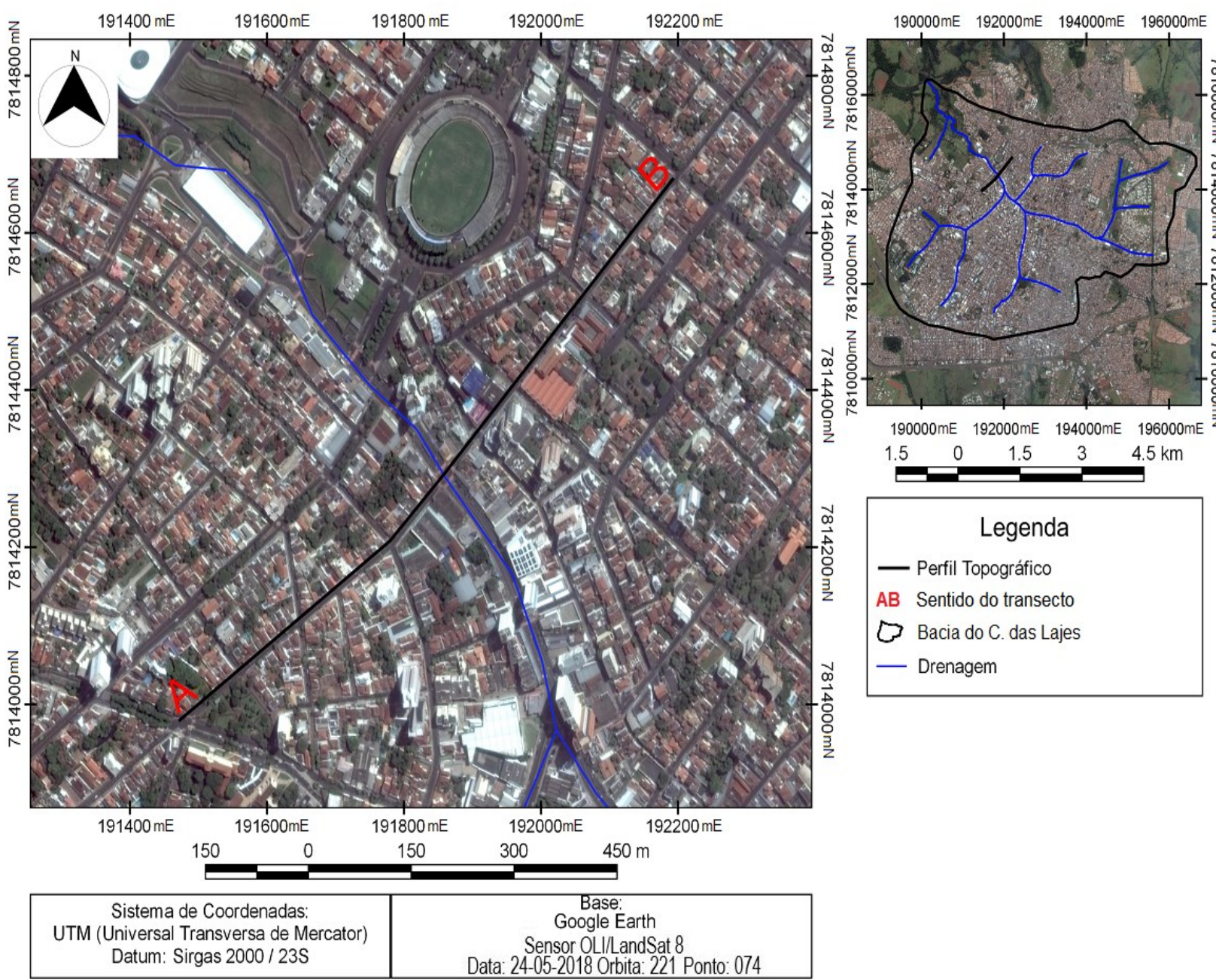

Perfil Topográfico - Rua Jaime Bilharinho

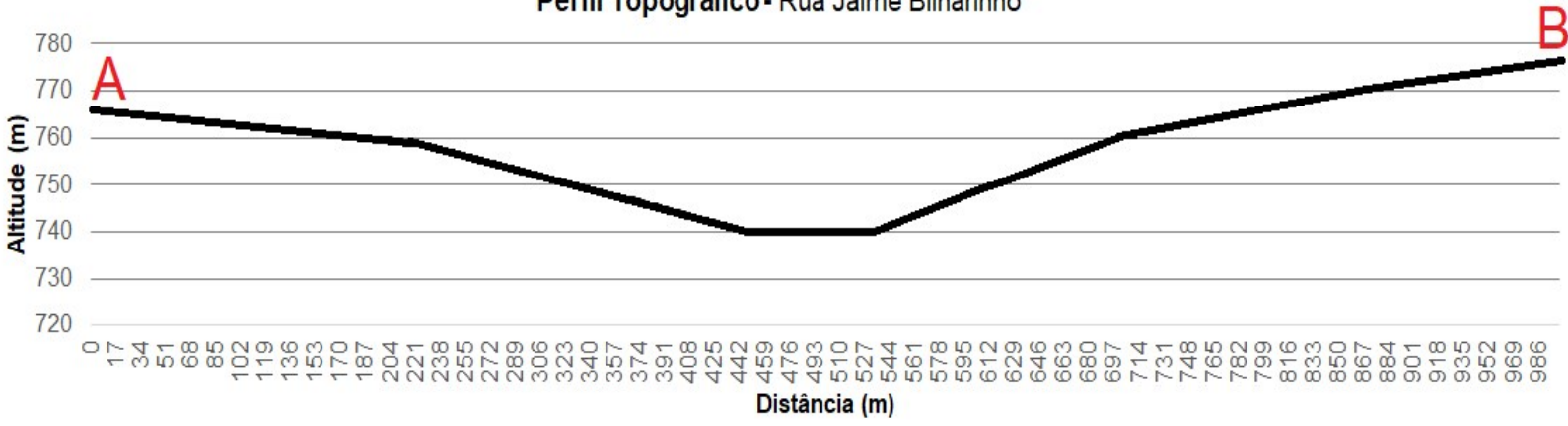

. Org. - by the Authors, 2019. 
Figure 6 - Transect (over another point of the road network) used to prepare one of the topographic profiles in Lajes Stream watershed.
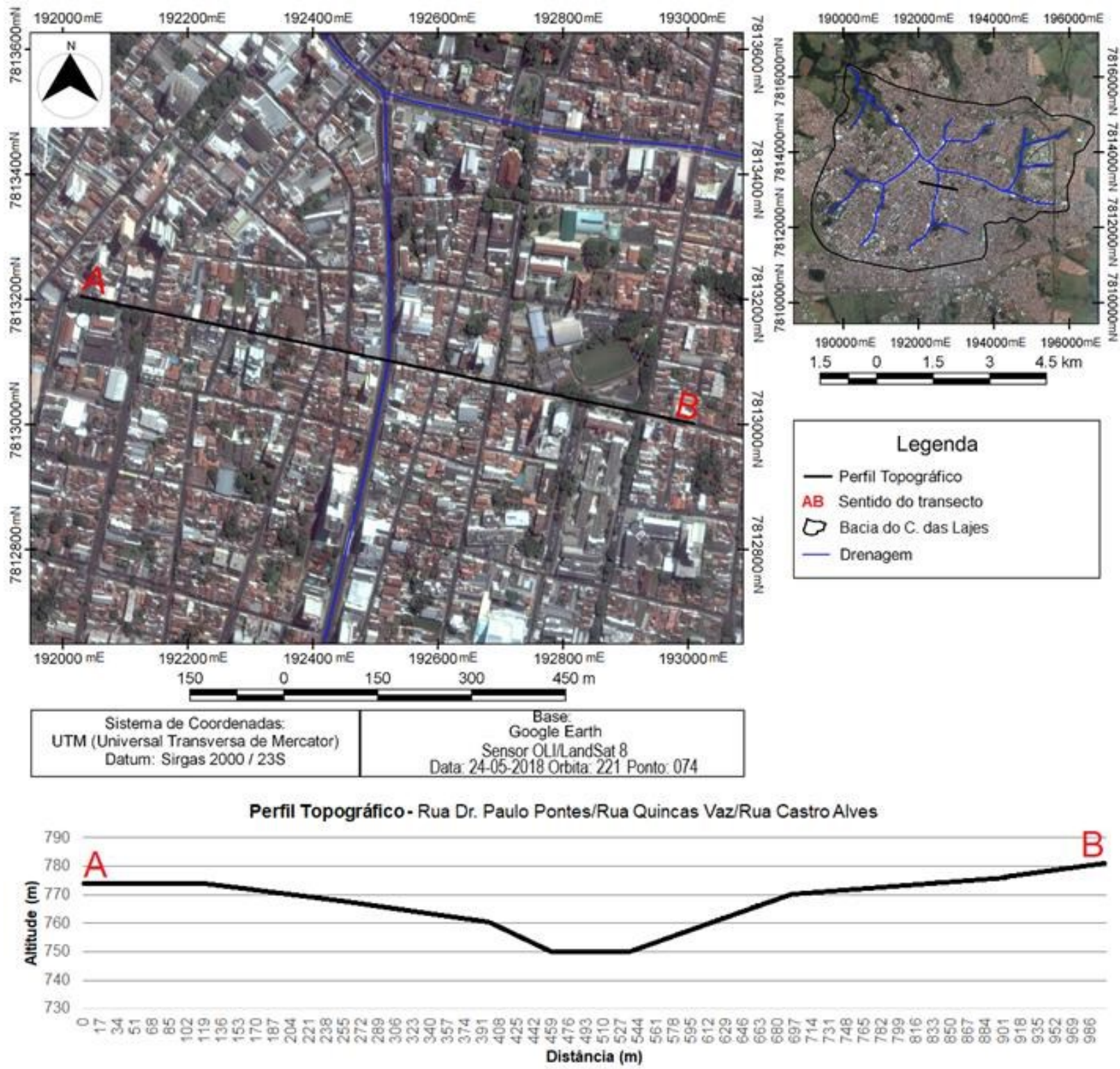

Org. - by the Authors, 2019.

\section{TOPOMORPHOLOGICAL COMPARTMENTS}

According to Ab'saber (1969), topomorphological compartmentalization is defined as the differentiation of morphological domains, based on specific features such as shape, which results from morphogenetic processes deriving from internal and external actions that are associated with the source material and structure of the site.

Topomorphological compartments are transformed based on the need of anthropic expansion, i.e., tops are flattened, slopes are changed to present lower steep, valley bottoms cease to exist, among other transformations that directly, or indirectly, change the entire local dynamics of the environment (MAGESH et al., 2013).

Thus, the geomorphological approach adopted in different studies enables coherent environmental planning, since understanding the local terrain allows selecting areas with lower environmental liabilities, as well as preventing tragedies. It is noteworthy that man appropriates the terrain and 
changes all geomorphological processes, which leads to predictable and unimaginable impacts (MARQUES NETO et al., 2017).

Topographic profiles generated in Lajes Stream watershed allowed identifying three topomorphological compartments and generating their three-dimensional representations (Figure 9).

Figure 7 - East/West topographic profile in the watershed. Transect location, see figure 9.

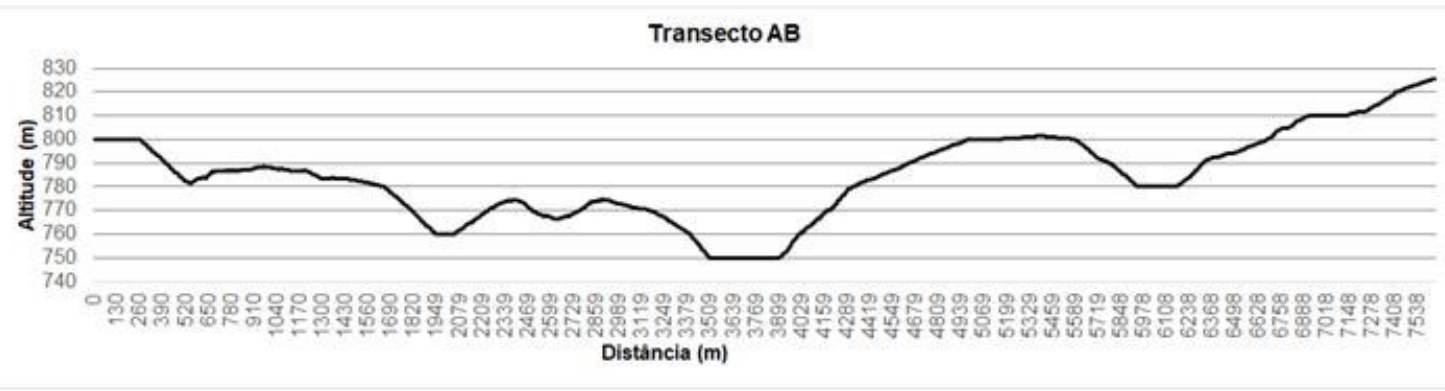

Org. - by the Authors, 2019.

Figure 8 - North/South topographic profile in the watershed. Transect location, see figure 9.

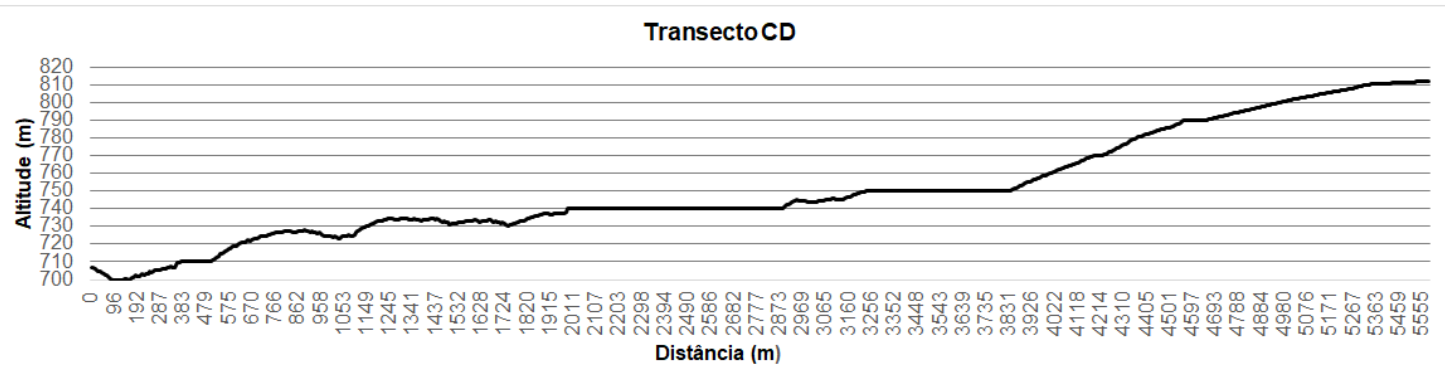

Org. - by the Authors, 2019.

\section{a. Valley Bottom Compartment (VBC) and adjacent areas}

This compartment comprises terrain portions whose altitude ranges from 700 to $750 \mathrm{~m}$; covering approximately $1.9 \mathrm{~km}^{2}$, which corresponds to $7.12 \%$ of the watershed. Civil defense agency classifies these areas as critical, since they are often subjected to flood events; besides, they are inserted in the Controlled-Densification Macrozone, which encompasses neighboring areas whose occupation is conditioned to the implementation of flood control structures.

The most striking geoforms found in this compartment lie on flat flood area, tributaries in its final section and valley bottom areas located near the runoff region; it is located after the west bus terminal, where canal incision and talweg characterization is not easy to be accomplished because they were fully resized by urban drainage works implemented over decades.

The most representative morphological feature in this compartment is the flat flood area, which acts like a floodplain. It occupies a relatively small central portion of the compartment and follows a narrow section in the N-NW direction alongside the canal.

This compartment is the place where the energy balance of Lajes Stream watershed takes place. Hortonian flows (materials and sediments) converge to a physical central point of the watershed. A sharp inflection ( $\mathrm{kp}$ ) is likely to happen along the longitudinal topographic profile of the watershed (Figure 3), a fact that may lead to rupture in the slope whose drainage channels are anthropized or cannot enable the outflow of the converging water volume.

However, overflows, flood events and inundations are expected to happen depending on the natural functioning of this environmental system. In addition, urbanization effects and lack of areas and/or techniques to enable rainwater infiltration and generate Hortonian runoff in watershed upstream areas increase water flow concentration in the aforementioned region.

$\begin{array}{lllll}\text { Caminhos de Geografia } & \text { Uberlândia-MG } & \text { v. 21, n. } 78 & \text { Dez/2020 } & \text { p. 253-269 Página } 263\end{array}$


Figure 9 - Geomorphological compartments of Lajes Stream watershed.
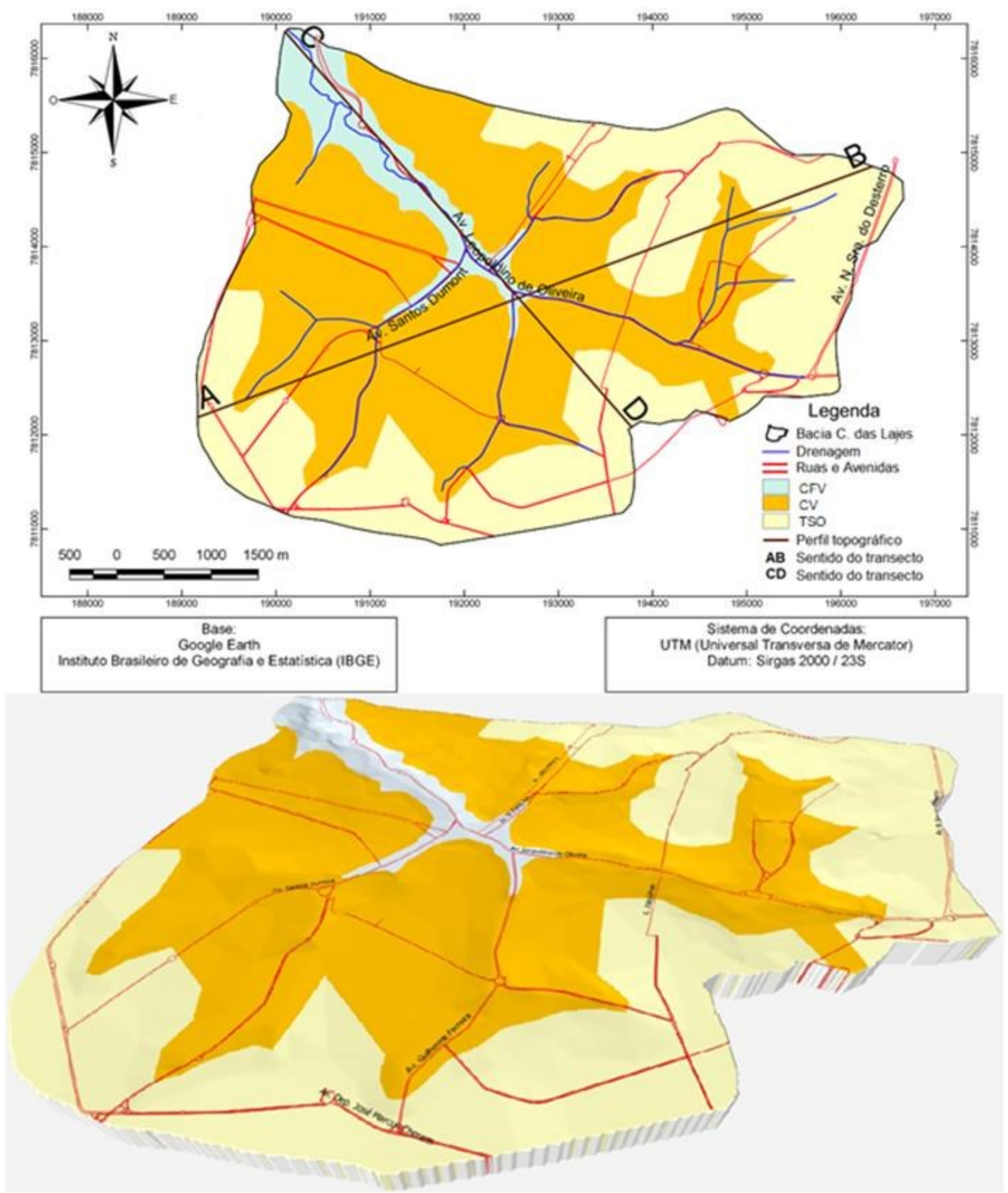

Org. - by the Authors, 2019.

This aspect corroborates Silva et al (2013), who pointed out that in case of intense rainfall, flood events in the downtown area result from the inefficiency of submerged galleries in draining the whole water volume that is diverted towards the downtown area due to channeling and/or rectification processes.

Thus, bad weather-related events observed in the study site are associated with changes implemented in Lajes Stream watershed region, either with the urbanization process, which appropriates topomorphological compartments, or with channeling procedures that change the natural course of the stream, or even with soil waterproofing processes, which hinder rainwater infiltration. 


\section{b. Mid-Slope Compartment (MSC)}

This compartment, which covers an area of approximately $13.9 \mathrm{~km}^{2}$ and corresponds to $52.06 \%$ of Lajes Stream watershed area, was the largest unit identified in the study site. It covers the mid-slope areas of the watershed and presents altitude ranging from 751 to $790 \mathrm{~m}$.

This compartment holds the areas presenting the steepest slopes; one of its most striking features lies on intermittent headwaters, which form springs (terminology used to refer to a point at which water flows from the ground during rainy periods.

Gobbo (2014) has generated a map of spring points in order to analyze the quality of the water of Uberaba River springs; based on such map, most springs are outside Lajes Stream watershed area. This scenario results from intense soil sealing in the downtown area of Uberaba County, a fact that changed the drainage system and led to the disappearance of springs.

This finding corroborates Rodrigues (2016), according to whom the remaining springs in the watershed may disappear in the future due to intense waterproofing of the soil surrounding them, in association with soil exposure in the areas surrounding the watershed, which leads to soil sedimentation deriving from erosive processes caused by increased surface runoff.

All measured locations presented intense anthropogenic interference due to high population density in the surrounding areas, a phenomenon that resulted in soil waterproofing and in other urban infrastructure construction processes associated with housing, recreation, among others.

Based on the analysis of Lajes Stream watershed waterproofing map (figure 2), as well as on field observations, this unit is intensely built in its whole extension and its largest waterproofed areas result from anthropic occupation processes that changed the natural morphodynamics of the watershed.

The waterproofing process in the watershed, mainly in the aforementioned unit, has partially stopped sediment production and changed the morphodynamic balance of this environmental system, a fact that caused negative synergistic balance in its compartments. Sediment deficit does not reflect in this unit, but in the subsequent topomorphological unit at lower altitude (VBC), where the final balance of this whole process takes place.

This outcome is corroborated by the fact that high flow velocities resulting from steep slopes in MSC are intrinsically associated with landscape modeling, which, a priori, should gradually soften the steeper areas along the drainage channels due to erosion.

Sukopp and Werner (1991) apud Valaski and Nucci (2012) have stated that the maximum waterproofing in the downtown area of a given city should not exceed $2 / 3$ of it, as well as that the remaining part of it should comprise permeable, non-build areas presenting vegetation. However, according to a recent study conducted by Sousa, Alamy Filho and Coelho (2016), the waterproofed area in the watershed covers approximately $22 \mathrm{~km}^{2}(82.4 \%$ of its entire territory). The aforementioned index is similar to the one recorded for the same area in the present study, which found approximately $86 \%$ waterproofed area.

\section{c. Gentlly Undulating Top (GUT) Compartment}

This compartment refers to an area presenting minimum and maximum altimetric variations corresponding to $790 \mathrm{~m}$ and $819 \mathrm{~m}$, respectively. It is the most distant from watercourses and covers approximately $10.9 \mathrm{~km}^{2}$ of Lajes Stream watershed $(40.82 \%$ of its territory). The compartment is virtually flat and presents slopes lower than $3 \%$, where the main avenues of the county were built. This area presents the lowest urban density and holds part of the springs that give origin to tributaries.

Since the MSC unit presents high waterproofing rates, GUT has to play the role of capturing and recharging downstream underground flows in order to help forming and maintaining subsuperficial flows. The most striking geomorphological feature of this unit lies on the flat tops of gently undulating hills.

Consequently, the GUT compartment has relatively flat surfaces in comparison to MSC. Its function in the environmental system lies on acting as a water catchment, recharge and infiltration zone, since low slopes and shear energy do not play a significant role in sediment production; therefore, this area is classified as an expressive sediment source, since its contribution to sediment production in the environmental system of the watershed is not significant. 
Studies conducted by Crepani et al. (2001) have shown that flat-to-gently undulating terrains, such as flattened hilltops, constitute low-fragility areas that enable greater stability in these terrains. These places are not subjected to flood events due to favorable terrain dynamics and to water flow direction towards other compartments.

\section{FINAL CONSIDERATIONS}

The current study has identified three topomorphological compartments (Valley Bottom, Mid-Slopes and Gently Undulating Tops), which presented individual topomorphological features and morphodynamics. The current topomorphological compartments derive from the morphological watershed reconfiguration that, in its turn, resulted from the urbanization and appropriation of valley bottom areas, slopes and gently undulating tops.

The first compartment, which is formed by tributaries, valley bottom areas, rectified channels and floodplains, presents natural tendency to experience flood events. The second compartment is the one presenting the highest slope, as well as intermittent headwaters and springs in its whole extension. In addition, it is heavily built, a fact that impairs the return flow. The third compartment has the smallest urban density and incorporates most of the springs, whose water flows into the main collector channel. This place accounts for flow capture and recharge processes; thus, it plays an essential role in maintaining the quality of the hydrological system in the area.

The natural dynamics of the environmental system in Lajes Stream watershed has inherent and innate features that favor the incidence of flood events, as evidenced by morphometric indicators, by concave lines with slope inflection points in longitudinal profiles and by a supposed flat area at low altitude sites that act as floodplains. Recurrent flood events and erosion processes observed in the main channel are consistent with the fact that the environmental system remains under construction, or in adjustment process, due to anthropogenic occupation. This assumption is corroborated by the lack of sedimentation and/or siltation processes.

\section{ACKNOWLEDGMENTS}

The authors express their thanks to FAPEMIG for the grant of a master's scholarship in the Environmental Sciences and Technology Program (Programa de Ciências e Tecnologia Ambiental).

\section{REFERENCES}

AB'SÁBER, A. N. Províncias geológicas e domínios morfoclimáticos no Brasil. São Paulo: Instituto de Geografia da USP, Geomorfologia, n. 15. 1969, 15p.

ANCHUELA, Ó. P.; SAINZ A. M. C.; JUAN, A. P.; GARBÍ, H. G. Assessing karst hazards in urbanized areas. Case study and methodological considerations in the mantle karst from Zaragoza city (NE Spain).Engineering Geology, Auckland, Nova Zelândia, v. 184, p.29-42, 2015.https://doi.org/10.1016/i.enggeo.2014.10.025

BACCARO, C. A. D. Unidades Geomorfológicas do Triângulo Mineiro. In: Revista Sociedade \& Natureza. Uberlândia, 3 (5 e 6): 37-42, dezembro 1991.

BACCARO, C. A. D.; FERREIRA, I. L.; ROCHA, M. R.; RODRIGUES, S. C. Mapa geomorfológico do Triângulo Mineiro: uma abordagem morfoestrutural-escultural. Revista Sociedade \& Natureza, Uberlândia, MG, v. 13, n. 25, p. 115-127, 2001.

BATHRELLOS, G. D.; GAKI-PAPANASTASSIOU, K.; SKILODIMOU, H. D.; PAPANASTASSIOU, D.; CHOUSIANITIS, K. G. Potential suitability for urban planning and industry development using natural hazard maps and geological-geomorphological parameters. Environmental earth sciences, v. 66, n. 2, p. 537-548, 2012.https://doi.org/10.1007/s12665-011-1263-x

BERHANE, G.; WALRAEVENS, K. Geological and geotechnical constraints for urban planning and natural environment protection: a case study from Mekelle City, Northern Ethiopia. 
Environmental Earth Sciences, [s.l.], v. 69, n. 3, p.783-798, 2012.https://doi.org/10.1007/s12665-0121963-X

BIGARELLA, J. J. Estrutura e origem das paisagens tropicais e subtropicais. 2. ed.Florianópolis: Ed. da UFSC, 2007.

BROOKES, A. Channelized rivers perspectives for environmental management. Wiley, Chichester, 1988. 326p.https://doi.org/10.1002/esp.3290150312

CABRAL, A. S. C. Os córregos ocultos na paisagem urbana: o caso da bacia do Carajás. Anagrama, São Paulo, SP, v. 5, n. 3, p. 1-34, 2012.

CARDOSO, C. A.; DIAS, H. C. T.; SOARES, C. P.; MARTINS, S. V. Caracterização Morfométrica da Bacia Hidrográfica do Rio Debossan. Revista Árvore, Nova Friburgo, RJ, v. 30, p. 241- 248, 2006.http://dx.doi.org/10.1590/S0100-67622006000200011

CARVALHO, T. M. de; LATRUBESSE, E. M. Aplicação de modelos digitais do terreno (MDT) em análises macrogeomorfológicas: 0 caso da bacia hidrográfica do Araguaia.Revista Brasileira de Geomorfologia, [s.I.], v. 5, n. 1, p.85-93, 6 dez. 2004.https://doi.org/ 10.20502/rbg.v5i1.34

CHRISTOFOLETTI, A. Geomorfologia - São Paulo: Edgard Blucher: FAPESP, 1979. 189 p.

CHRISTOFOLETTI, A. Geomorfologia fluvial - São Paulo: Edgard Blucher: FAPESP, 1981. 313 p.

CODEMIG - Companhia de Desenvolvimento Econômico de Minas Gerais. Projeto Triângulo Mineiro - Folha Uberaba - Igarapava. SE.23-Y-C-IV - SF.23-V-A-I. Escala 1:100.000. Programa mapeamento geológico do Estado de Minas Gerais. 2017.

CORREAA, L. L. P. Análise estratégica de decisão aplicada à seleção de áreas para expansão urbana visando o controle de inundações na área urbana do município de Uberaba. 2003. 107f. Dissertação (Mestrado em Engenharia Civil) - Universidade Federal de Viçosa, Viçosa. 2003.

CREPANI, E.; MEDEIROS, J. S.; HERNANDEZ FILHO, P, FLORENZANO, T. G.; DUARTE, V.; BARBOSA, C. C. F. Sensoriamento remoto e geoprocessamento aplicados ao zoneamento ecológico-econômico e ao ordenamento territorial. São José dos Campos: INPE; 2001.

DANTAS, M, TEIXEIRA, S Origem das Paisagens. In: João, X, Teixeira, S, Fonseca, D (orgs.) Geodiversidade do Estado do Pará. CPRM, Belém, p. 23-52, 2013.

ETCHEBEHERE, M. L.; SAAD, A. R.; FULFARO, V. J.; PERINOTTO, J. A. J. Aplicação do Índice "Relação Declividade-Extensão-RDE" na Bacia do Rio do Peixe (SP) para detecção de deformações neotectônicas. Geologia USP. Série Científica, v. 4, n. 2, p. 43-56, 2004.https://doi.org/10.5327/S1519-874X2004000200004

GOBBO, C. G. R. Avaliação da potabilidade das águas e dos impactos ambientais macroscópicos das nascentes em Uberaba, Minas Gerais, 2014. 114f. Dissertação (Mestrado Profissional em Inovação Tecnológica), Programa de Mestrado Profissional em Inovação Tecnológica, Universidade Federal do Triângulo Mineiro.

HORTON, R. E. Erosional development of streams and their drainage basins: Hydrographical approach to quantitative morphology. Geological Society of America Bulletin, v.56, n.2, p.275-370, 1945.https://doi.org/10.1130/0016-7606(1945)56[275:EDOSAT]2.0.CO;2

IBGE - Instituto Brasileiro de Geografia e Estatística. Manual Técnico de Geomorfologia. Coordenação de recursos naturais e estudos ambientais. 2 ed. Rio de Janeiro: IBGE, 2009.

IGAM - Instituto Mineiro de Gestão das Águas. Hidrografia: Base para arquivo SHP.2002. Disponível em: <http://www.igam.mg.gov.br/banco-de-noticias/1-ultimasnoticias/1312-hidrografia>. Acessed: March 08, 2018.

MAGESH, N. S.; JITHESHLAL, K. V.; CHANDRASEKAR, N.; JINI, K. V. Geographical information system-based morphometric analysis of Bharathapuzha river basin, Kerala, India. Applied Water Science, v. 3, n. 2, p. 467-477, 2013.https://doi.org/10.1007/s13201-013-0095-0

MANSIKKANIEMI, $H$. The sinuosity of rivers in northern Finland. Publicationes Instituti Geographicic Universitatis Turkuensis, v. 52, p. 16-32, 1970.

$\begin{array}{lllll}\text { Caminhos de Geografia } \quad \text { Uberlândia-MG } & \text { v. 21, n. } 78 \quad \text { Dez/2020 } & \text { p. 253-269 Página } 267\end{array}$ 
MARQUES NETO, R.; SILVA, F. P., FERNANDES, R. A.; BARRETO, J. C.; EDUARDO, C. C. A espacialidade do relevo em paisagens transformadas e sua representação: mapeamento geomorfológico da Bacia do Rio Paraibuna, Sudeste de Minas Gerais. Raega - O Espaço Geográfico em Análise, v. 41, p. 65-81, 2017.http://dx.doi.org/10.5380/raega.v41i0.49186

MORAIS, O. R. Enchentes em Uberaba. 2001. 140 f. Monografia (Especialização em Educação Ambiental), Faculdade de Zootecnia de Uberaba (FAZU), Uberaba, 2001.

OLIVEIRA, E. L. A.; RECKZIEGEL, B. W.; ROBAINA, L. E. S. Modificações na morfologia dos canais de drenagem da Bacia Hidrográfica do Arroio Cadena, Santa Maria/RS. Revista RAEGA, Curitiba, n. 11, p. 103-113, 2006.http://dx.doi.org/10.5380/raega.v11i0.7752

PETTS, G. E.; AMOROS, C. Fluvial Hydrosystems. London: Chapmann \& Hall, 1996. 307p.

PMU - Prefeitura Municipal de Uberaba. Relatório ambiental projeto Água Viva. Uberaba, 2005a. $260 \quad$ p. Disponível em: $<$ http://www.uberaba.mg.gov.br/portal/acervo/agua viva/arquivos/avaliacao ambiental/Relatorio\%20A mbiental\%201.pdf>Acessed: April 20, 2018.

PMU - Prefeitura Municipal de Uberaba. Relatório de avaliação ambiental projeto Água Viva Sumário Executivo. Uberaba, 2005b. 260 p. Disponível em: $<$ http://www.uberaba.mg.gov.br/portal/acervo/agua viva/arquivos/avaliacao ambiental/Relatorio\%20A mbiental\%202.pdf>. Acessed: April 20, 2018.

PMU - Prefeitura Municipal de Uberaba. Estudo de impacto ambiental e relatório de impacto ambiental dos reforços nos canais centrais da macrodrenagem urbana do centro da cidade de Uberaba, estado de Minas Gerais. 2009. Disponível em: $<$ http://www.uberaba.mg.gov.br/portal/acervo/agua viva/arquivos/EIA-RIMA\%20\%20LICENCIAMENTO\%20-\%20Projeto\%20Agua\%20Viva.pdf>. Acessed: April 08, 2018.

ROCHA, J. S. M. Manual de manejo integrado de bacias hidrográficas. Santa Maria: Imprensa Universitária, 1997. 423p.

RODRIGUES, J. P. S. Avaliação da qualidade ambiental urbana na bacia hidrográfica do Córrego das Lajes em Uberaba (MG) - período de 1994 a 2014. 2016. 127f. Dissertação (Mestrado em Geografia) Universidade Federal de Goiás, 2016.

SANTOS, L; BACCARO, C. A. D. Caracterização geomorfológica da Bacia do Rio Tijuco. Caminhos de geografia, Uberlândia, v. 5, n. 11, p. 1-21, 2004.

SILVA, M. F.; SARDINHA, D. S.; MARTINS, P. D. M. D.; POLETO, C. Sistemas de amortecimento de cheias do parque das acácias na cidade de Uberaba (MG). Fórum Ambiental da Alta Paulista, v. 9, n. 2, p. 416-432, 2013.http://dx.doi.org/10.17271/19800827922013657

SOUSA, J. S.; ALAMY FILHO, J. E.; COELHO, G. Influência da impermeabilização e das áreas de preservação permanente no volume do escoamento superficial e vazão de pico, na Bacia do Córrego das Lajes-Uberaba, MG. Scientia Agraria, v. 16, n. 3, 2016.http://dx.doi.org/10.5380/rsa.v16i3.46828

SOUZA, J. S. Áreas de preservação permanente urbanas: mapeamento, diagnósticos, índices de qualidade ambiental e influência no escoamento superficial: estudo de caso: Bacia do Córrego das Lajes, Uberaba/MG. 2008, 160f. 2008. Dissertação (Mestrado em Engenharia Civil) - Faculdade de Engenharia Civil, Universidade Federal de Uberlândia, Uberlândia, 2008.

STRAHLER, A. N. Hypsometric (area-altitude) - analysis of erosion al topography.Geological Society of America Bulletin, v.63, n.10, p.1117-1142, 1952.https://doi.org/10.1130/00167606(1952)63[1117:HAAOET]2.0.CO;2

TAROLLI, P.; SOFIA, G.; CAO, W. The Geomorphology of the Human Age.Encyclopedia of the Anthropocene, [s.I.], p.35-43, 2018.https://doi.org/10.1016/B978-0-12-409548-9.10501-9

VALASKI, S.; $\mathrm{NUCCI}, \mathrm{J}$. C. Cobertura vegetal arbórea em condomínios residenciais horizontais do bairro Santa Felicidade - Curitiba/Pr. Geografia Ensino \& Pesquisa, Santa Maria, v. 16, n. 1, p 103-115. 2012.https://doi.org/10.5902/223649947325 
VILLELA, S. M.; MATTOS, A. Hidrologia aplicada. McGraw-Hill do Brasil, São Paulo, 1975. p.245.

WESCHE, T. A. Stream channel modifications and reclamation structures to enhance fish habitat. In: GORE, J. A. (Ed.). The Restoration of Rivers and Streams: Theories and Experience, chapter 5. Boston: Butterworth Publishers, 1985. p.103-163.

Recebido em: 22/03/2020

Aceito para publicação em: 28/09/2020 